\title{
PERAN IKATAN NOTARIS INDONESIA (INI) DALAM PENETAPAN TARIF DIANTARA NOTARIS KOTA BALIKPAPAN
}

\author{
Nindy Putri, Paramita Prananingtyas \\ Magister Kenotariatan, Fakultas Hukum, Universitas Diponegoro \\ J1. Imam Barjo Pleburan, Semarang, 50241 \\ nindynindyaputri@gmail.com,pptyas@yahoo.com
}

\begin{abstract}
The determination of notary honorarium constitutes an essential factor of cost imposition for people who want to use notary service or as the criterion in order to avoid tariff warfare between the notaries thus the unfair competition does not exist. This research used Juridical Empirical research as the method. Based on the discussions, it could be concluded that: The agreement of tariff determination which conducted by the notary is legal for the provision of Undang-undang Anti Monopoli dan Persaingan Usaha Tidak Sehat, The effort which is done by regional board of INI in order to prevent unfair competition could be conducted preventively and repressively, The form of supervision from regional board of INI was conducted through regional council.
\end{abstract}

Keywords: Notary, Notary Honorarium.

\begin{abstract}
Abstrak
Penetapan honorarium Notaris merupakan suatu faktor penting yang menjadi dasar pengenaan tarif bagi masyarakat yang ingin menggunakan jasa Notaris juga sebagai patokan agar tidak terjadi perang tarif diantara para Notaris sehingga tidak memunculkan persaingan tidak sehat antara Notaris. Metode yang digunakan adalah menggunakan penelitian hukum Yuridis Empiris. Berdasarkan pembahasan dapat diketahui bahwa Perjanjian penetapan tarif yang dilakukan oleh Notaris tidak melanggar ketentuan Undang-undang Anti Monopoli dan Persaingan Usaha Tidak Sehat; upaya yang dilakukan oleh Pengda INI Kota Balikpapan guna mencegah persaingan tidak sehat bisa dilakukan secara preventif maupun secara represif dan bentuk pengawasan yang dilakukan oleh Pengda INI dilakukan melalui Dewan Kehormatan Daerah.
\end{abstract}

Kata Kunci: Notaris, Honorarium Notaris

\section{A. Pendahuluan}

Profesi notaris telah lama dikenal di Indonesia, bahkan jauh sebelum Indonesia merdeka yaitu pada masa pemerintahan kolonial Belanda. Pada awalnya keberadaan notaris merupakan suatu kebutuhan bangsa Eropa di Indonesia dalam upaya untuk menciptakan akta autentik, khususnya dalam bidang perdagangan.(Sulihandari, 2013)

Seiring dengan pembangunan nasional yang semakin cepat berkembang dan kemajuan dalam berbagai bidang dewasa ini peran dan fungsi notaris terus diperlukan dan semakin berkembang, hal inilah yang tampaknya membuat profesi notaris kian diminati untuk ditekuni agar kebutuhan akan jasa notaris tetap dapat terpenuhi.

Notaris merupakan perpanjangan tangan dari pemerintah dalam hal ini negara, dimana negara telah memberikan kepercayaan kepada Notaris untuk menjalankan sebagian urusan atau tugas negara khususnya dalam bidang hukum perdata (Dewi, 2011), sehingga pihak yang telah memangku jabatan sebagai Notaris akan memiliki tanggung jawab untuk senantiasa menjaga harkat dan martabat serta kehormatan profesi Notaris. Seseorang yang memangku jabatan Notaris untuk 
menjaga hal tersebut wajib tunduk oleh seperangkat peraturan perundang-undangan yang mengatur tentang jabatan Notaris, yaitu Undang-undang Nomor 2 Tahun 2014 tentang Perubahan Undangundang Nomor 30 Tahun 2004 tentang Jabatan Notaris.

Undang-undang Nomor 2 Tahun 2014 tentang Perubahan Undang-undang Nomor 30 Tahun 2004 tentang Jabatan Notaris berisi peraturan yang mengatur diantaranya mengenai ketentuan umum yang berisikan pengertian-pengertian yang terkait dengan Notaris, pengangkatan dan pemberhentian Notaris, kewenangan dan kewajiban serta larangan bagi setiap Notaris, tempat kedudukan dan formasi serta wilayah jabatan Notaris, cuti Notaris dan Notaris pengganti, honorarium atas jasa yang diberikan Notaris, akta Notaris, minuta akta, pengambilan minuta akta dan pemanggilan Notaris, pengawasan, organisasi Notaris, sanksi atas pelanggaran Notaris, kewenangan majelis pengawas untuk mengawasi terlaksananya Undang-undang Jabatan Notaris tersebut.

Beberapa ketentuan yang diubah dari Undang-undang Nomor 30 Tahun 2004 yang kemudian dituangkan kedalam Undang-undang Nomor 2 Tahun 2014 yang telah disahkan oleh Presiden Susilo Bambang Yudhoyono pada tanggal 15 Januari 2014 antara lain yaitu tentang penguatan syarat untuk dapat diangkat menjadi Notaris, penambahan kewajiban, larangan merangkap jabatan, dan alasan pemberhentian sementara Notaris, pengenaan kewajiban kepada calon Notaris yang sedang melakukan magang, penyesuaian pengenaan saksi pada pasal tertentu, pembedaan terhadap isi akta baik yang bersifat mutlak maupun yang bersifat relatif, pembentukan Majelis Kehormatan Notaris, penguatan dan penegasan Organisasi Notaris, penegasan untuk menggunakan bahasa Indonesia sebagai bahasa resmi dalam pembuatan akta autentik, serta penguatan fungsi, wewenang, dan kedudukan Majelis Pengawas.

Peraturan mengenai jabatan notaris selain Undang-undang tentang Jabatan Notaris terdapat pula Kode Etik Notaris yang dirumuskan oleh Ikatan Notaris Indonesia (INI). Berdasarkan Pasal 1 huruf b Kode Etik Notaris Ikatan Notaris Indonesia (INI), Kode Etik Notaris dan untuk selanjutnya akan disebut Kode Etik adalah seluruh kaidah moral yang ditentukan oleh Perkumpulan Ikatan Notaris Indonesia yang selanjutnya akan disebut "Perkumpulan" berdasar keputusan Kongres Perkumpulan dan/atau yang ditentukan oleh dan diatur dalam peraturan perundang-undangan yang mengatur tentang hal itu dan yang berlaku serta wajib ditaati oleh setiap dan semua anggota perkumpulan dan semua orang yang menjalankan tugas jabatan sebagai Notaris, termasuk di dalamnya para Pejabat Sementara Notaris, Notaris Pengganti dan Notaris Pengganti Khusus.

Kode Etik disusun dan dirancang oleh Ikatan Notaris Indonesia (INI) yang berdasarkan Kode Etik Notaris Pasal 1 huruf a memiliki arti bahwa Ikatan Notaris Indonesia disingkat INI adalah Perkumpulan/organisasi bagi para Notaris, berdiri semenjak tanggal 1 Juli 1908, diakui sebagai Badan Hukum (rechtpersoon) berdasarkan penetapan pemerintah (Gouvernements Besluit) tanggal 5 September 1908 Nomor 9, merupakan satu-satunya wadah pemersatu bagi semua dan setiap orang yang memangku dan menjalankan tugas jabatan sebagai pejabat umum di Indonesia, yang berisikan tentang aturan perilaku setiap Notaris dan harus ditaati oleh setiap Notaris baik didalam maupun diluar jabatannya. Kode Etik Notaris secara umum memuat pengertian-pengertian yang terkait dengan Kode Etik Notaris, ruang lingkup Kode Etik Notaris, kewajiban dan larangan serta pengecualian, sanksi, tata cara penegakan Kode Etik Notaris, pemecatan sementara, kewajiban pengurus Ikatan Notaris Indonesia dan sebagainya. 
Kode Etik Notaris juga membentuk Dewan Kehormatan untuk mengawasi terlaksananya aturan-aturan yang tersebut dalam Kode Etik Notaris. Kode Etik ini dirumuskan agar setiap Notaris dapat mengemban profesinya tetap dalam koridor yang sebenarnya dan membantu penegakan hukum karena Notaris merupakan salah satu profesi hukum yang ada di Indonesia.

Dirumuskannya Undang-undang Jabatan Notaris dan Kode Etik Notaris dengan harapan agar pengemban profesi notaris mampu berjalan sesuai dengan kaidah hukum yang ada agar dalam menjalankan profesi jabatannya akan tetap pada koridor yang benar dan tidak melenceng dari aturan-aturan tersebut, sehingga Notaris sebagai salah satu profesi hukum yang memang seharusnya turut membantu penegakan hukum sesuai bidangnya dapat membuat hal tersebut terwujud.

Berbeda dengan apa yang diharapkan, seiring dengan berjalannya waktu dan banyak diminatinya profesi Notaris dari waktu kewaktu, ditambah dengan perkembangan teknologi dan adanya kesempatan bagi sebagian Notaris untuk mendapatkan klien sebanyak mungkin dengan cara instan dan tidak lazim, hal ini membuat sebagian oknum Notaris tergiur untuk melenceng dari aturan-aturan yang ada. Tanpa disadari hal tersebut menimbulkan adanya persaingan dikalangan sebagian Notaris itu sendiri. Persaingan tersebut bahkan semakin menjurus kepada persaingan tidak sehat antar sesama Notaris agar oknum Notaris mendapatkan banyak klien.

Persaingan antar rekan Notaris tersebut kian lama semakin menjurus kepada persaingan usaha yang tidak sehat antar rekan Notaris itu sendiri. Mereka turun ke pasar mendatangi klien, menawarkan jasa, melakukan negosiasi honor dan melakukan perikatan layaknya pebisnis pada umumnya (Pengurus Pusat Ikatan Notaris Indonesia, 2008). Salah satu penyebab timbulnya persaingan usaha tidak sehat antar rekan Notaris adalah penetapan tarif jasa Notaris atau honorarium di bawah standar yang telah ditetapkan oleh Undang-undang dan Kode Etik. Hal tersebut sangat bertentangan dengan apa yang diatur dalam Undang-Undang Nomor 2 Tahun 2014 tentang Jabatan Notaris maupun Kode Etik Notaris, karena Notaris dilarang melakukan upaya penetapan jasa tarif dibawah standar untuk mendapatkan klien sebanyak mungkin, akan tetapi dalam prakteknya terdapat oknum Notaris yang melakukan hal tersebut.

Hal tersebut memicu persaingan yang tidak sehat antar rekan Notaris yang lain karena ada sebagian Notaris yang tetap berpegang teguh pada aturan Undang-undang dan Kode Etik Notaris.

Peraturan tentang larangan persaingan tidak sehat diatur dalam Undang-undang Nomor 5 Tahun 1999 tentang Larangan Praktek Monopoli Dan Persaingan Usaha Tidak Sehat. Persaingan tidak sehat diantara Notaris merupakan dampak dari penetapan tarif jasa Notaris di bawah standar dapat dikaitkan dengan Undang-undang Nomor 5 Tahun 1999 karena Undang-undang tersebutlah yang mengatur secara khusus mengenai persaingan usaha tidak sehat. Persaingan usaha tidak sehat sendiri menurut Pasal 1 huruf F Undang-undang Nomor 5 Tahun 1999 adalah "persaingan antar pelaku usaha dalam menjalankan kegiatan produksi dan/atau pemasaran barang dan/atau jasa yang dilakukan dengan cara tidak jujur atau melawan hukum atau menghambat persaingan usaha.”

Pelaku usaha yang dimaksud dalam Undang-undang Nomor 5 Tahun 1999 secara garis besar dapat meliputi perorangan atau badan usaha. Notaris sendiri dapat dikatakan sebagai pelaku usaha, dikarenakan Notaris adalah perorangan yang menyediakan dan memberikan jasa dibidangnya kepada masyarakat yang memerlukan jasanya dan atas jasa yang diberikannya kepada masyarakat, Notaris berhak memungut honor dari pekerjaanya. 
Penetapan tarif jasa Notaris dibawah standar yang dilakukan oleh beberapa oknum Notaris sebagaimana disebutkan diatas dapat dikaitkan dengan persaingan usaha tidak sehat yang diatur dalam Undang-undang Nomor 5 Tahun 1999 karena jelas menyalahi aturan mengenai honorarium yang telah ditetapkan dalam Undang-undang Nomor 2 Tahun 2014 tentang Perubahan UndangUndang Nomor 30 Tahun 2004 tentang Peraturan Jabatan Notaris dan juga Kode Etik Notaris.

Penetapan tarif Notaris dibawah standar dilakukan beberapa oknum Notaris dikarenakan beberapa alasan, diantarannya:

a. Notaris berpikir bahwa jika pekerjaan tersebut tidak diambil maka akan diambil oleh pihak lain karena masih banyak notaris yang bersedia mengerjakannya;

b. Pekerjaan tersebut terpaksa diambil karena membutuhkan biaya untuk operasional kantor;

c. Upaya untuk menjaga harkat martabat diri sebagai seorang notaris dan ada beban psikologis yaitu rasa malu bila tidak memiliki klien.

Penetapan tarif Notaris dibawah standar yang menimbulkan persaingan tidak sehat antar Notaris tentu saja dapat menimbulkan permasalahan tersendiri, bukan hanya sebatas pada sesama rekan Notaris, namun juga terhadap Notaris yang bersangkutan itu sendiri. Menciptakan kesenjangan antar rekan Notaris dalam suatu wilayah tertentu sehingga menimbulkan ketidak harmonisan hubungan dengan antar rekan seprofesi yang semestinya dapat saling membantu dan saling merhargai, selain itu hal tersebut juga dapat merendahkan profesi Notaris yang seharusnya dijaga oleh pengemban jabatan Notaris serta telah melanggar Undang-undang Jabatan Notaris serta Kode Etik dan sumpah jabatan yang mewajibkan setiap Notaris untuk senantiasa berprilaku jujur dan mejaga kehormatan dan martabat serta tanggung jawab profesi Notaris.

Beberapa hal yang telah disebutkan diatas adalah sebagian pelanggaran yang menyalahi Undang-undang dan Kode Etik Notaris, selain itu masih banyak hal lain yang dilakukan oleh oknum Notaris yang dapat dikategorikan sebagai persaingan usaha tidak sehat diantara rekan Notaris. Larangan mengenai persaingan yang dapat mengakibatkan timbulnya persaingan tidak sehat diatara notaris tentu saja telah diatur secara jelas dalam Undang-undang Jabatan Notaris dan Kode Etik Notaris. Pada akhirnya tergantung pada bagaimana mental masing-masing individu pemangku jabatan profesi Notaris untuk menegakan aturan.

Peranan Ikatan Notaris Indonesia (INI) sebagai satu-satunya organisasi yang menaungi notaris-notaris di Indonesia tentu saja memiliki peran dan fungsi sangat penting guna mencegah pelanggaran hukum dan/atau segala macam persaingan tidak sehat yang dilakukan oleh beberapa oknum notaris.

Berdasarkan uraian dalam latar belakang tersebut, maka dalam penulisan ini akan mengkaji mengenai masalah sebagaimana berikut ini:

1) Bagaimana bentuk perjanjian penetapan harga dalam penetapan tarif yang dilakukan oleh para notaris di Balikpapan?

2) Bagaimana upaya yang dilakukan oleh Ikatan Notaris Indonesia (INI) Balikpapan untuk mencegah persaingan antara notaris menjadi tidak sehat melalui penetapan tarif?

3) Bagaimana bentuk pengawasan dari Ikatan Notaris Indonesia (INI) terhadap perilaku dan tindakan notaris di Balikpapan agar tidak muncul persaingan yang tidak sehat melalui penetapan tarif? 


\section{B. Metode Penelitian}

Dalam sebuah penelitian tidak mungkin mampu menemukan, merumuskan, menganalisis, maupun memecahkan masalah tertentu untuk mengungkap sebenarnya tanpa penggunaan metodologi yang tepat. Menurut Ronny Hannitijo Soemitro:

Di dalam metodologi penelitian hukum diuraikan mengenai penalaran, dalil-dalil, postulatpostulat belakang setiap langkah dalam proses yang lazim memberikan alternatif dan petunjukpetunjuk dalam memilih alternatif tersebut serta membandingkan unsur-unsur penting dalam penelitian hukum.(Soemitro, 2000)

Metode penelitian yang digunakan dalam penulisan penelitian ini adalah sebagai berikut: Metode pendekatan yang digunakan dalam penelitian ini adalah metode pendekatan Yuridis Empiris. Metode penelitian hukum yuridis empiris adalah suatu metode penelitian hukum yang berfungsi untuk melihat hukum dalam artian nyata dan meneliti bagaimana bekerjanya hukum di lingkungan masyarakat, atau dengan kata lain yaitu suatu penelitian yang dilakukan terhadap keadaan sebenarnya atau keadaan nyata yang terjadi di masyarakat dengan maksud untuk mengetahui dan menemukan fakta-fakta dan data yang dibutuhkan, kemudian setelah data yang dibutuhkan terkumpul selanjutnya menuju pada identifikasi masalah yang pada akhirnya menuju pada penyelesaian masalah.(Waluyo, 2002)

Pendekatan yuridis empiris ini dilakukan terhadap permasalahan yang akan diteliti dengan memperhatikan norma-norma hukum yang berlaku dan dihubungkan dengan fakta-fakta yang ditemui saat penelitian dengan melihat berbagai aspek yang terdapat di dalam Peranan Ikatan Notaris Indonesia (INI) dalam penetapan tarif diantara notaris, studi di Kota Balikpapan.

Penelitian yang dilakukan dalam penelitian ini bersifat deskriptif analisis, yaitu penelitian yang menggambarkan situasi atau peristiwa yang sedang diteliti dan kemudian dianalisis berdasarkan fakta-fakta berupa data primer maupun data sekunder dengan bahan hukum primer, bahan hukum sekunder, dan bahan hukum tersier (Soemitro, 2000), yang relevan dengan Peranan Ikatan Notaris Indonesia (INI) guna mencegah persaingan tidak sehat diantara notaris, studi di Kota Balikpapan.

Tahap Penelitian yang pertama adalah Penelitian Kepustakaan. Penelitian kepustakaan ini menggunakan data sekunder, yang terdiri dari: Bahan hukum primer, yaitu pengkajian terhadap peraturan perundang-undangan yang terkait dengan Peranan Ikatan Notaris Indonesia (INI) dalam penetapan tarif diantara notaris, studi di Kota Balikpapan., yaitu:

a) Undang-Undang Dasar Negara Republik Indonesia Tahun 1945 Amandemen ke-4.

b) Undang-undang Nomor 30 Tahun 2004 Jo Undang-undang Nomor 2 Tahun 2014 tentang Jabatan Notaris.

c) Undang-undang Nomor 5 tahun 1999 tentang Larangan praktek monopoli dan persaingan usaha tidak sehat..

d) Kode etik Notaris.

Bahan hukum sekunder, yaitu yang terkait dengan Peranan Ikatan Notaris Indonesia (INI) dalam penetapan tarif diantara notaris (studi di kota Balikpapan) yang ditulis oleh para ahli yang diperoleh dari buku-buku. Bahan hukum tersier, yaitu yang membantu bahan hukum primer dan bahan hukum sekunder seperti kamus Inggris - Indonesia, kamus hukum, dan internet. Penelitian 
Lapangan dimaksudkan untuk memperoleh data primer yang diperoleh, untuk mendapatkan korelasi dengan penelitian yang sedang dilakukan. Penelitian lapangan dilakukan dengan melakukan dialog dan tanya jawab dengan pihak-pihak yang akan dapat memberikan informasi yang dibutuhkan dalam penelitian ini. Teknik pengumpulan data dilakukan dengan tahap: Studi Dokumen, yaitu melakukan penelitian terhadap dokumen-dokumen yang berhubungan dengan peranan Ikatan Notaris Indonesia (INI) dalam penetapan tarif diantara notaris (studi di Balikpapan), Wawancara, yaitu proses tanya jawab secara lisan di mana dua orang atau lebih berhadapan secara fisik antara penanya atau interviewer dengan pemberi informasi atau responden.(Soemitro, 2000). Teknik ini dilakukan debgan proses interaksi dan komunikasi secara lisan.

Alat Pengumpul data dalam penelitian kepustakaan (library research) yaitu menginventarisasi bahan hukum dan berupa catatan tentang bahan-bahan yang relevan dengan Peranan Ikatan Notaris Indonesia (INI) dalam penetapan tarif diantara notaris (studi di kota Balikpapan).. Alat bantu pengumpul data dalam penelitian lapangan (field research) berupa daftar pertanyaan, alat perekam, dan flashdisk.

Analisis Data, Sesuai dengan metode pendekatan yang digunakan, maka data yang diperoleh untuk penulisan hukum selanjutnya akan dianalisis dengan menggunakan analisis yuridis kualitatif, yaitu seluruh data yang diperoleh diinventarisasi, dikaji, dan diteliti secara menyeluruh, sistematis, dan terintegrasi untuk mencapai kejelasan masalah yang akan dibahas.(Soemitro, 2000)

\section{Hasil Penelitian dan Pembahasan}

\section{Bentuk Perjanjian Penetapan Harga Dalam Penetapan Tarif Yang Dilakukan Oleh Para Notaris di Balikpapan}

Notaris sebagai pejabat umum, sekaligus sebuah profesi, posisinya sangat penting dalam membantu memberikan kepastian hukum bagi masyarakat. Notaris harus mencegah terjadinya permasalahan hukum di kemudian hari melalui akta autentik yang dibuatnya sebagai alat pembuktian yang sempurna di pengadilan.

Notaris merupakan profesi yang terhormat selalu lekat dengan etika dan dengan etikalah Notaris berhubungan dengan pekerjaanya. Tanpa etika, Notaris hanyalah robot-robot mekanis yang bergerak dalam tanpa jiwa. Karena lekatnya etika pada profesi Notaris disebut sebagai profesi mulia (officium nobile).(Anshori, 2009)

Notaris disebut pejabat umum atau publik karena Notaris diangkat dan diberhentikan oleh Pemerintah, Notaris menjalankan tugas Negara, dan akta yang dibuat, yaitu minuta (asli akta) adalah merupakan dokumen Negara. Pejabat umum adalah pejabat yang diangkat dan diberhentikan oleh kekuasaan umum (Pemerintah) dan diberi wewenang serta kewajiban untuk melayani publik dalam hal-hal tertentu. Notaris adalah pejabat umum atau publik yang diangkat dan diberhentikan oleh pemerintah, namun Notaris bukan merupakan pegawai pemerintah atau pegawai negeri yang memperoleh gaji dari pemerintah. Keberadaan Notaris sebagai pejabat umum atau publik yang bertugas untuk membuat akta tidak mendapat honor dari negara, oleh karena itu Notaris berhak menerima honorarium ( fee) atas jasa hukum yang diberikan sesuai dengan kewenangannya.

Notaris dalam menerima honorarium atau imbalan dari para penghadap atau klien atas jasa hukum yang diberikan dalam membuat akta autentik sesuai dengan kewenangannya membuat akta autentik dan mempunyai suatu dasar hukum yang jelas. Dasar hukum dari pada pengenaaan 
honorarium atau imbalan kepada para penghadap atau/ klien adalah berdasarkan nilai ekonomis dan nilai sosiologis dari setiap akta yang dibuatnya, hal ini diatur di dalam Undang-Undang Jabatan Notaris Pasal 36 ayat 1 sampai dengan ayat 4 yaitu :

1) Notaris berhak menerima honorarium atas jasa hukum yang diberikan sesuai dengan kewenangannya.

2) Besarnya honorarium yang diterima oleh Notaris didasarkan pada nilai ekonomis dan nilai sosiologis dari setiap akta yang dibuatnya.

3) Nilai ekonomis sebagaimana dimaksud pada ayat (2) ditentukan dari objek setiap akta sebagai berikut:

a) Sampai dengan Rp 100.000.000,- (seratus juta rupiah) atau ekuivalen gram emas pada saat itu, honorarium yang diterima paling besar adalah 2,5\% (dua koma lima persen)

b) Di atas Rp 100.000.000,-- (seratus juta rupiah) sampai dengan Rp 1.000.000.000,- (satu miliyar rupiah) honorarium yang diterima paling besar 1,5\% (satu koma lima persen)

c) Diatas Rp 1.000.000.000,- (satu miliyar rupiah) honorarium yang diterima didasarkan atas kesepakatan antara Notaris dengan pihak, tetapi tidak melebihi $1 \%$ (satu persen) dari objek yang dibuat aktanya.

4) Nilai sosiologis ditentukan berdasarkan fungsi sosial dari objek setiap akta dengan honorarium yang diterima paling besar Rp 5.000.000,- (lima juta rupiah).

Dalam pemungutan honorarium seperti tertulis di atas, Notaris harus memperhatikan ketentuan-ketentuan mengenai hal apa saja yang membolehkan untuk memungut atau menetapkan honorarium kepada para kliennya. Sangat perlu diperhatikan, tidak semua akta yang dibuat oleh Notaris bernilai ekonomis, sebagai contoh akta yang tidak bernilai ekonomis antara lain akta pendirian yayasan, akta pendirian sekolah, akta wakaf dan akta pendirian rumah ibadah.

Secara tegas disebutkan pada Pasal 36 ayat 1 Undang-Undang Jabatan Notaris yang tertulis di atas, Notaris berhak menerima honorarium atas jasa hukum yang diberikan sesuai dengan kewenanganya. Dengan kata lain, Notaris dilarang atau tidak diperbolehkan memungut honorarium kepada kliennya di luar kewenanganya tersebut.

Pasal 36 Undang-undang Jabatan Notaris itulah yang kemudian menjadi dasar penetapan tarif jasa Notaris di Indonesia, begitu pula di Kota Balikpapan Provinsi Kalimantan Timur.

Penentuan honorarium Notaris mengacu kepada Undang-Undang Jabatan Notaris dan juga didasarkan pada Kode Etik Notaris yang tertuang dalam Petunjuk Pelaksanaan dan/atau Peraturan Pelaksanaan yang dibuat oleh Ikatan Notaris Indonesia (I.N.I) sebagai organisasi yang menaungi profesi Notaris. Besaran honorarium di masing-masing wilayah kerja tentunya berbeda, ini merupakan suatu perbedaan yang pasti terjadi dalam profesi Notaris.

Besaran honorarium Notaris ada yang diatas harga standar maupun dibawah harga standar yang telah ditetapkan oleh perkumpulan Ikatan Notaris Indonesia (I.N.I), hal ini diatur dalam Pasal 3 ayat 13 Kode Etik Notaris Ikatan Notaris Indonesia. Pengemban profesi Notaris diharapkan mampu menjalankan profesi jabatannya tetap pada koridor yang benar dan tidak melanggar dari aturanaturan di atas, sehingga Notaris sebagai salah satu profesi hukum yang memang seharusnya turut membantu penegakkan hukum sesuai bidangnya dapat membuat hal tersebut terwujud, khususnya dalam penetapan besaran honorarium Notaris atas jasa hukum yang diberikan sesuai dengan 
kewenangannya. Terjadinya penetapan besaran honorarium yang memiliki perbedaan-perbedaan khususnya di penetapan besaran minimal honorarium Notaris.

penetapan besaran minimal honorarium Notaris yang di tetapkan oleh organisasi Notaris dalam hal ini Ikatan Notaris Indonesia (I.N.I.) Balikpapan sudah mempunyai peraturan yang tegas terhadap Notaris di kota Balikpapan, begitu pula seharusnya diikuti oleh seluruh regional lain di seluruh Indonesia untuk menyusun besaran minimal honorarium Notaris sesuai regional masingmasing.

Berdasarkan hasil wawancara dengan Ketua Pengurus Daerah Ikatan Notaris Indonesia Kota Balikpapan, Yenny Wuryandari, S.H., penetapan nilai minimum honorarium Notaris yang diatur oleh perkumpulan jabatan Notaris, dibuat dengan mempertimbangkan banyak faktor di dalamnya, yakni;

a) Undang-undang atau peraturan yang berlaku;

b) Nilai transaksi yang dikerjakan;

c) Kondisi perekonomian daerah;

d) Kondisi ekonomi klien;

e) Kondisi sosiologis-antropologis.

Dasar pertimbangan sebagaimana tersebut di atas sudah sangat ideal, tetapi mungkin dalam implementasinya akan banyak mengalami kesulitan, misalnya nilai transaksi, jika melakukan transaksi jual beli tanah, fakta dilapangan menunjukkan bahwa nilai transaksi tanah yang akan dijual sangat sulit dilakukan karena adanya perbedaan antara harga Nilai Jual Objek Pajak (NJOP) dan nilai jual sesungguhnya, oleh karena itu akan terjadi tawar menawar nilai transaksi, dan pada gilirannya menyebabkan kesulitan dalam penentuan tarif.

Demikian juga penggunaan kondisi ekonomi klien, sangat manusiawi dan idealis. Penilaian terhadap kondisi ekonomi klien juga bukan hal yang mudah. Jika tidak ada ukuran yang jelas, penggunaan kondisi ekonomi klien sebagai dasar pertimbangan penentuan honorarium Notaris akan tetap bisa menimbulkan persaingan yang tidak sehat antar Notaris, karena klien sebagai pengguna jasa Notaris akan berupaya melakukan tawar-menawar serendah mungkin dan akan membandingkan antara Notaris satu dengan Notaris lain, sehingga hal ini akan merendahkan harkat martabat jabatan Notaris.

Para Notaris yang setuju dengan adanya peraturan honorarium mengemukakan bahwa walaupun ada peraturan yang mengikat dan mempunyai daya paksa, hendaknya peraturan tersebut mampu melindungi hak Notaris secara keseluruhan, sebagai payung hukum bagi Notaris, sehingga sampai kapanpun tidak akan menjerat para Notaris kepada masalah-masalah hokum yang mungkin akan mucul di kemudian hari.

Berdasarkan hasil wawancara dengan Amirullah, salah satu notaris di Balikpapan, honorarium menunjang kinerja Notaris agar tetap bekerja secara profesional. Penentuan standar maksimal honorarium Notaris yang ditentukan dalam Undang-undang diatur guna melindungi masyarakat yang memakai jasa Notaris agar tidak dikenai biaya yang terlalu tinggi, sedangkan penentuan standart minimal honorarium Notaris diatur guna melindungi Notaris agar tidak mendapat honorarium yang terlalu kecil dan diharapkan akan sangat membantu menjaga profesionalitas Notaris dalam menjalankan profesinya. 
Dalam Undang-undang Nomor 5 Tahun 1999 Tentang Larangan Praktek Monopoli dan Persaingan Usaha Tidak Sehat menjelaskan bahwa, Penetapan harga (price fixing) adalah perjanjian dilarang yang dilakukan oleh para pelaku usaha pesaingnya untuk menetapkan harga atas mutu suatu barang dan atau jasa yang harus dibayar oleh konsumen atau pelanggan pada pasar bersangkutan yang sama. Penetapan tarif honorarium Notaris adalah penetapan yang didasarkan pada Undangundang yang berlaku. Penetapan tarif honorarium tersebut diatur dengan jelas dalam Pasal 36 Undang-undang Nomor 2 Tahun 2014 tentang perubahan atas Undang-undang Nomor 30 Tahun 2004 tentang Jabatan Notaris dan juga diatur dalam Kode Etik Notaris Ikatan Notaris Indonesia (I.N.I), jadi penetapan tarif ini adalah penetapan tarif yang dikecualikan dari ketentuan Undangundang Nomor 5 Tahun 1999 Tentang Larangan Praktek Monopoli dan Persaingan Usaha Tidak Sehat karena merupakan perjanjian yang didasarkan pada ketentuan perundang-undangan yang berlaku.

\section{Upaya Yang Dilakukan Oleh Ikatan Notaris Indonesia (INI) Untuk Mencegah Persaingan Antara Para Notaris Menjadi Tidak Sehat Melalui Penetapan Tarif.}

Notaris sebagai salah satu profesi hukum harus menjalankan jabatannya sesuai dengan Undangundang Nomor 2 Tahun 2014 tentang Perubahan Undang-undang Nomor 30 Tahun 2004 tentang Jabatan Notaris dan Kode Etik Notaris. Seiring ketatnya persaingan dikalangan Notaris, mendorong para Notaris untuk melakukan segala cara dalam rangka mendapatkan klien secara instan dengan melanggar ketentuan Undang-undang dan Kode Etik yang berakibat pada timbulnya persaingan yang tidak jujur antar sesama Notaris. Di dalam praktik khususnya kota Balikpapan terdapat berbagai bentuk persaingan tidak jujur yang kemudian dapat dikategorikan sebagai persaingan usaha tidak sehat.

Nurhayati, S.H., M.Kn, salah satu Notaris di kota Balikpapan menyebutkan bahwa perilakuperilaku Notaris yang tergolong sebagai persaingan tidak sehat adalah sebagai berikut:

a. Mempromosikan jabatan baik melalui media cetak atau elektronik;

b. Memperkerjakan seseorang yang masih berstatus karyawan di kantor Notaris lain yang terlebih dahulu membuka kantor di Balikpapan;

c. Penetapan tarif jasa notaris di bawah standar.

Tegasnya pengaturan mengenai tarif yang telah diatur dalam Undang-undang Jabatan Notaris dan penetapan yang telah dibuat oleh organisasi profesi yaitu Ikatan Notaris Indonesia (I.N.I) nyatanya hanya sebatas daftar tarif di atas kertas saja. Praktiknya di lapangan banyak Notaris yang melanggar ketentuan tersebut karena kurangnya kesadaran diri dari masing-masing Notaris untuk mematuhi peraturan yang berlaku.

Penetapan tarif di bawah standar bisa dilakukan oleh Notaris langsung kepada klien yang datang kepadanya atau bisa juga dengan cara melakukan kerja sama dengan pihak-pihak tertentu seperti Developer, Bank, atau Bank Perkreditan Rakyat (BPR). Kerjasama tersebut biasanya terjadi negosiasi mengenai tarif yang akan ditetapkan oleh Notaris dan biasanya Notaris akan memberikan tarif yang lebih rendah dari standar yang telah ditetapkan.

Persaingan yang semakin meningkat dikarenakan banyaknya jumlah Notaris yang menjabat pada suatu daerah menjadi faktor terbesar yang membuat Notaris mengabaikan ketentuan tarif tersebut. Ketentuan justru dilanggar dengan melakukan praktik "banting harga" untuk mendapatkan 
klien sebanyak-banyaknya. Hal inilah yang kemudian berdampak pada timbulnya persaingan tidak sehat antar rekan Notaris, meskipun persaingan adalah merupakan satu kondisi yang wajar, akan tetapi akan menimbulkan permasalahan tersendiri jika dilakukan dengan cara-cara yang tidak wajar terlebih lagi jika melanggar peraturan perundang-undangan yang ada.

Merujuk pada ketentuan Undang-Undang Jabatan Notaris dan Kode Etik Notaris memang tidak menyebutkan dengan tegas bahwa penetapan tarif di bawah standar dapat menimbulkan persaingan tidak jujur antar Notaris. Bentuk persaingan yang dilakukan dengan menetapkan tarif di bawah standar yang dilakukan dengan cara kerjasama dengan instansi tertentu bisa menimbulkan persaingan tidak jujur antar sesama Notaris, dan kerja sama tersebut akan menciptakan suatu monopoli oleh Notaris tersebut yang menutup kemungkinan bagi Notaris lain untuk ikut berpartisipasi, jika hal tersebut tetap dilakukan, tentu saja juga dapat merugikan klien karena akta yang dihasilkan tersebut proses pembuatannya melanggar ketentuan perundang-undangan.

Upaya yang dilakukan oleh Ikatan Notaris Indonesia (I.N.I) Balikpapan untuk mencegah persaingan antara Notaris menjadi tidak sehat melalui penetapan tarif dapat dilakukan dengan beberapa langkah, yaitu: Pembinaan oleh Institusi terkait, Koordinasi dan kerja sama antara Notaris dan Ikatan Notaris Indonesia (I.N.I), dan pengawasan yang berkelanjutan.

Upaya penegakan tidak hanya dilakukan oleh Ikatan Notaris Indonesia (I.N.I), tetapi Notaris perlu memperhatikan apa yang disebut sebagai perilaku profesi yang memiliki unsur-unsur sebagai berikut: Memiliki integeritas moral yang mantap, harus jujur terhadap klien maupun diri sendiri (kejujuran intelektual), sadar akan batas-batas kewenangannya, tidak semata-mata berdasarkan pertimbangan uang.

\section{Bentuk Pengawasan Dari Ikatan Notaris Indonesia (I.N.I) Terhadap Perilaku Dan}

Tindakan Notaris Di Balikpapan Agar Tidak Muncul Persaingan Yang Tidak Sehat Melalui Penetapan Tarif

Dalam melakukan pekerjaannya seorang Notaris harus mengikuti rambu-rambu agar tidak melenceng dan berakibat melakukan pelanggaran-pelanggaran terhadap Undang-undang Jabatan Notaris. Kontrol dari pemerintah terhadap profesi Notaris diemban oleh Majelis Pengawas Notaris yang terdapat ditingkat kebupaten propinsi dan pusat. suatu mekanisme pengawasan sangat diperlukan agar pelaksanaan norma hukum dan kode etik profesi notaris tersebut berjalan sesuai dengan yang diharapkan, sedangkan Pengawasan terhadap pelaksanaan kode etik Notaris dilakukan oleh Dewan Kehormatan Notaris yang terdapat di bawah Ikatan Notaris Indonesia.

Dalam Pasal 7 Kode Etik Notaris dijelaskan bahwa Pengawasan atas pelaksanaan Kode Etik itu dilakukan dengan cara sebagai berikut :

i. Pada tingkat pertama oleh Pengurus Daerah Ikatan Notaris Indonesia dan Dewan Kehormatan Daerah;

ii. Pada tingkat banding oleh Pengurus Wilayah Ikatan Notaris Indonesia dan Dewan Kehormatan Wilayah;

iii. Pada tingkat akhir oleh Pengurus Pusat Ikatan Notaris. Indonesia dan Dewan Kehormatan Pusat.

Pengawasan merupakan tindakan atau proses kegiatan untuk mengetahui hasil pelaksanaan, kesalahan, kegagalan untuk kemudian dilakukan perbaikan dan mencegah terulangnya kembali 
kesalahan-kesalahan itu, begitu pula menjaga agar pelaksanaannya tidak berbeda,dengan rencana yang ditetapkan.

Pengawasan terhadap Notaris mengarah pada penegakan aturan-aturan hukum yang membatasi ruang lingkup jabatan Notaris. Tujuan pengawasan terhadap para Notaris ialah agar para Notaris sedapat mungkin memenuhi persyaratan-persyaratan yang telah ditetapkan oleh Undangundang dan Kode Etik Notaris demi kepentingan masyarakat umum yang dilayaninya.

Pengawasan Notaris dibedakan antara perilaku dan tindakan yang dilakukan oleh Notaris dalam menjalankan jabatanya oleh Majelis Pengawas, sedangkan perilaku dan tindakan yang dilakukan oleh Notaris diluar menjalankan jabatanya diawasi oleh Dewan Kehormatan Notaris. Pengawasan tersebut pada dasarnya adalah merupakan wujud dari perlindungan hukum terhadap Notaris itu sendiri oleh karena dengan adanya suatu pengawasan, maka setiap Notaris dalam berperilaku dan tindakannya baik dalam menjalankan jabatannya maupun diluar jabatannya selalu dalam koridor hukum.

Mekanisme pengawasan terhadap profesi Notaris diatur secara ideal dalam peraturan perundang-undangan dan menjadi bagian yang tidak dapat dipisahkan dari realitas sosial masyarakat hukum yang berhubungan langsung dengan profesi ini. Pengawasan merupakan salah satu aspek penegakan hukum yang harus selalu diperhatikan dan dilaksanakan dalam lingkungan penegak hukum termasuk pengawasan terhadap Notaris.

Penegakan hukum selalu melibatkan manusia-manusia didalamnya, dengan demikian akan melibatkan tingkah laku manusia juga, oleh karena itu hukum baru dapat dilaksanakan secara efektif apabila diikuti dengan pengawasan atau mekanisme kontrol yang kuat dari pihak yang ditunjuk berdasarkan peraturan perundang-undangan, dengan demikian profesi hukum yang dijalankan tetap pada koridor etika profesi dan sesuai dengan pelaksanaan jabatannya, sehingga kepercayaan masyarakat sebagai pengguna jasa Notaris akan tetap terjaga.

Pengawasan dimaksud merupakan kegiatan yang bersifat preventif dan kuratif. Bersifat Preventif mengandung makna suatu proses pembinaan, sedangkan bersifat kuratif mengandung makna melakukan penjatuhan sanksi terhadap Notaris dalam pelaksanaan jabatannya apabila terbukti melakukan pelanggaran terhadap Undang undang Nomor 30 tahun 2004 tentang Jabatan Notaris beserta Perubahannya Undang-undang Nomor 2 tahun 2014 dan pelanggaran terhadap Kode Etik Notaris. Ruang lingkup pengawasan ini lebih luas daripada ruang lingkup pengawasan kepada Notaris yang dilakukan oleh Majelis Pengawas Daerah sebagaimana telah diatur dengan jelas dan tegas dalam Undang-Undang Jabatan Notaris.

\section{Simpulan}

Berdasarkan uraian diatas, maka dapat disimpulkan bahwa bentuk perjanjian penetapan harga dalam penetapan tarif yang dilakukan oleh para Notaris di Balikpapan didasari oleh UndangUndang Nomor 2 Tahun 2014 tentang perubahan atas Undang-Undang Nomor 30 Tahun 2004 tentang Jabatan Notaris dalam pasal 36 ayat 1 sampai dengan 4 dan juga diatur dalam Peraturan Perkumpulan organisasi Kode Etik Notaris Ikatan Notaris Indonesia (I.N.I). Penetapan tarif Notaris yang diatur dalam Undang-undang Jabatan Notaris hanya seputar pembuatan akta dan mengatur batas maksimum honorarium saja. Perjanjian penetapan besaran minimal honorarium dan untuk jasa pelengkap akta seorang Notaris berpedoman pada Kode Etik Notaris, kemudian pengurus masing- 
masing daerah Ikatan Notaris Indonesia akan mengadakan kesepakatan antara semua anggota agar didapatkan hasil yang sesuai kesepakatan bersama. Dalam Undang-Undang Nomor 5 Tahun 1999 Tentang Larangan Praktek Monopoli dan Persaingan Usaha Tidak Sehat menjelaskan bahwa, Penetapan harga (price fixing) adalah perjanjian dilarang yang dilakukan oleh para pelaku usaha pesaingnya untuk menetapkan harga atas mutu suatu barang dan atau jasa yang harus dibayar oleh konsumen atau pelanggan pada pasar bersangkutan yang sama. Penetapan tarif honorarium Notaris adalah penetapan yang didasarkan pada Undang-undang yang berlaku. Penetapan tarif honorarium tersebut diatur dengan jelas dalam Pasal 36 Undang-undang Nomor 2 Tahun 2014 tentang perubahan atas Undang-undang Nomor 30 Tahun 2004 tentang Jabatan Notaris dan juga diatur dalam Kode Etik Notaris Ikatan Notaris Indonesia (I.N.I), jadi penetapan tarif ini adalah penetapan tarif yang dikecualikan dari ketentuan Undang-undang Nomor 5 Tahun 1999 Tentang Larangan Praktek Monopoli dan Persaingan Usaha Tidak Sehat karena merupakan perjanjian yang didasarkan pada ketentuan perundang-undangan yang berlaku.

Upaya yang dilakukan oleh Ikatan Notaris Indonesia (I.N.I) Balikpapan untuk mencegah persaingan antara Notaris menjadi tidak sehat melalui penetapan tarif dapat dilakukan dengan beberapa langkah, yaitu: Pembinaan oleh Institusi terkait, Koordinasi dan kerja sama antara Notaris dan Ikatan Notaris Indonesia (I.N.I), dan pengawasan yang berkelanjutan. Upaya penegakan tidak hanya dilakukan oleh Ikatan Notaris Indonesia (I.N.I), tetapi Notaris perlu memperhatikan apa yang disebut sebagai perilaku profesi yang memiliki unsur-unsur sebagai berikut: Memiliki integeritas moral yang mantap, harus jujur terhadap klien maupun diri sendiri (kejujuran intelektual), sadar akan batas-batas kewenangannya, tidak semata-mata berdasarkan pertimbangan uang.

Pengawasan dari Ikatan Notaris Indonesia (I.N.I) terhadap perilaku dan tindakan Notaris di Balikpapan agar tidak muncul persaingan yang tidak sehat melalui penetapan tarif : Pada tingkat pertama oleh Pengurus Daerah Ikatan Notaris Indonesia dan Dewan Kehormatan Daerah; Pada tingkat banding oleh Pengurus Wilayah Ikatan Notaris Indonesia dan Dewan Kehormatan Wilayah; Pada tingkat akhir oleh Pengurus Pusat Ikatan Notaris Indonesia dan Dewan Kehormatan Pusat. Pengawasan Notaris dibedakan antara perilaku dan tindakan yang dilakukan oleh Notaris dalam menjalankan jabatanya oleh Majelis Pengawas, sedangkan perilaku dan tindakan yang dilakukan oleh Notaris diluar menjalankan jabatanya diawasi oleh Dewan Kehormatan Notaris. Pengawasan tersebut pada dasarnya adalah merupakan wujud dari perlindungan hukum terhadap Notaris itu sendiri oleh karena dengan adanya suatu pengawasan, maka setiap Notaris dalam berperilaku dan tindakannya baik dalam menjalankan jabatannya maupun diluar jabatannya selalu dalam koridor hukum.

Berdasarkan simpulan diatas, maka disampaikan saran bahwa Notaris harus senantiasa mengingat sumpah jabatan yang telah dilakukan untuk taat dan patuh terhadap Perundang-undangan yang berlaku dan tidak melakukan pelanggaran-pelanggaran terhadap Undang-undang dan Kode Etik Notaris khususnya mengenai permasalahan penetapan honorarium di bawah standar yang telah ditetapkan dalan Undang-undang Jabatan Notaris.

Upaya untuk meminimalisir pelanggaran terhadap kode etik diperlukan sosialisasi dan pengawasan yang dilakukan secara terus menerus dan berkesinambungan oleh Ikatan Notaris 
Indonesia, selain hal tersebut diperlukan pengaturan yang tegas dalam pelaksanaannya tentang tata cara pengangkatan Notaris, khususnya tentang penerapan formasi Notaris, sehingga tidak menimbulkan peningkatan jumlah Notaris dalam suatu wilayah yang tidak sesuai dengan kebutuhan, hal ini tentu sangat berpengaruh dalam menekan terjadinya pelanggaran kode etik khususnya persaingan yang tidak sehat antara sesama Notaris.

Untuk kedepannya perlu dibenahi kerjasama yang telah dilakukan selama ini agar koordinasi dan kerjasama yang baik makin ditingkatkan berdasarkan silahturahim yang saling membutuhkan antara Notaris dan Ikatan Notaris Indonesia (I.N.I) sebagai pemersatu antara Notaris, Pengurus Ikatan Notaris Indonesia (I.N.I), Kementrian Hukum dan Hak Asasi Manusia, Dewan Kehormatan dan Majelis Pengawas melalui kegiatan ilmiah dan silahturahmi harus bisa memupuk rasa solidaritas profesi yang lebih baik, menjunjung perilaku yang sesuai dengan Kode Etik dan bekerja sama secara mutualisme dalam pengayaan materi keilmuan yang relevan dengan bidang kerja Notaris. Sangat diharapkan Ikatan Notaris Indonesia (I.N.I) melalui Dewan Kehormatan Notaris akan terus melakukan pengawasan sebagai upaya menjaga agar Notaris tidak melakukan pelanggaran kode etik. Pengawasan oleh Ikatan Notaris Indonesia (I.N.I) yang telah dilaksanakan harus lebih difokuskan dengan tujuan mencegah pelanggaran dan sebagai rambu efektivitas penegakan hukum yang lebih menjamin kepastian hukum, namun demikian tujuan pengawasan ini sebenarnya bukan hanya untuk pencegahan akan timbulnya pelanggaran, akan tetapi juga untuk mendukung penerapan Undang-undang Jabatan Notaris menuju kepastian hukum, secara moral juga mendukung efektifitas Kode Etik, dan secara represif juga untuk memberi rambu-rambu akan adanya hukuman/sanksi, bahwa perilaku, etik, dan pelaksanaan jabatan Notaris selalu dinilai dan diawasi oleh masyarakat melalui Majelis Pengawas dan Dewan Kehormatan.

\section{DAFTAR PUSTAKA}

Anshori, A. (2009). Filfasat Hukum. Yogyakarta : Gadjah Mada University Press.

Waluyo, B. (2002). Penelitian Hukum Dalam Praktek, Jakarta : Sinar Grafika, 2002.

Sulihandari, H. (2013). Prinsip-Prinsip Dasar Profesi Notaris. Cetakan I. Jakarta Timur : Dunia Cerdas, 2013.

Pengurus Pusat Ikatan Notaris Indonesia. (2008). Jati Diri Notaris Indonesia: Dulu, Sekarang Dan Dimasa Akan Datang. Cetakan I. Jakarta: Gramedia Pustaka.

Soemitro, R. (2000). Metodologi Penelitian Hukum dan Yudimetri. Bogor : Ghalia Indonesia.

Dewi,S. (2011). Panduan Teori Dan Praktik Notaris. Cetakan I. Yogyakarta: Pustaka Yustisia.

Undang-Undang Nomor 2 Tahun 2014 Tentang Perubahan Undang-Undang Nomor 30 Tahun 2004 Tentang Peraturan Jabatan Notaris.

Undang-Undang Nomor 5 Tahun 1999 Tentang Larangan Praktek Monopoli dan Persaingan Usaha Tidak Sehat

Kode Etik Notaris Ikatan Notaris Indonesia (I.N.I) 